Article

\title{
Analysis of the Possibility of Management of Curly-Leaf Pondweed for Energetic Purposes
}

\author{
Marcin Herkowiak ${ }^{1, *}$, Andrzej Osuch ${ }^{2} \mathbb{D}$, Ewa Osuch ${ }^{2} \mathbb{D}$, Bogusława Waliszewska $^{3}$ and Grzegorz Zając $^{4}(\mathbb{D}$ \\ 1 Institute of Technology and Life Sciences-National Research Institute, Falenty, Hrabska Avenue 3, \\ 05-090 Raszyn, Poland \\ 2 Department of Biosystems Engineering, Poznań University of Life Sciences, 50 Wojska Polskiego St., \\ 60-637 Poznań, Poland; andrzej.osuch@up.poznan.pl (A.O.); ewa.osuch@up.poznan.pl (E.O.) \\ 3 Department of Chemical Wood Technology, Poznań University of Life Sciences, Wojska Polskiego 38/42, \\ 60-637 Poznań, Poland; boguslawa.waliszewska@up.poznan.pl \\ 4 Department of Power Engineering and Transportation, Faculty of Production Engineering, University of Life \\ Sciences in Lublin, Głęboka 28, 20-612 Lublin, Poland; grzegorz.zajac@up.lublin.pl \\ * Correspondence: m.herkowiak@itp.edu.pl
}

Citation: Herkowiak, M.; Osuch, A.; Osuch, E.; Waliszewska, B.; Zając, G. Analysis of the Possibility of Management of Curly-Leaf Pondweed for Energetic Purposes. Energies 2021, 14, 5477. https:// doi.org/10.3390/en14175477

Academic Editor: Tiit Lukk

Received: 30 June 2021

Accepted: 13 August 2021

Published: 2 September 2021

Publisher's Note: MDPI stays neutral with regard to jurisdictional claims in published maps and institutional affiliations.

Copyright: (c) 2021 by the authors. Licensee MDPI, Basel, Switzerland. This article is an open access article distributed under the terms and conditions of the Creative Commons Attribution (CC BY) license (https:// creativecommons.org/licenses/by/ $4.0 /)$.

\begin{abstract}
The possibilities of using curly-leaf pondweed for energy purposes were analyzed. This plant contributes to overgrowth of water reservoirs, causing their eutrophication. The plants examined were from two different water reservoirs: Lake Winiary (Gniezno) and Lake Rusalka (Poznan). On the basis of the investigations, it was determined that it is possible to use curly-leaf pondweed for energy purposes, both in the combustion method and in the biomethane fermentation process. Studies were performed to assess the suitability of the plants for combustion as a solid biofuel and studies on the use of pondweed as a fermenter feedstock. The calorimetric study showed the possibility of obtaining more energy for the curly-leaf pondweed coming from Lake Rusalka. The heat of combustion of these plants was $13.95 \mathrm{MJ} \cdot \mathrm{kg}^{-1}$ (Winiary pondweed) and $9.10 \mathrm{MJ} \cdot \mathrm{kg}^{-1}$ (Rusalka pondweed). On the other hand, the calorific value of these plants was $12.60 \mathrm{MJ} \cdot \mathrm{kg}^{-1}$ (Winiary pondweed) and $7.80 \mathrm{MJ} \cdot \mathrm{kg}^{-1}$ (Rusalka pondweed). In the case of biogas yield studies, significantly higher biogas production was observed for Lake Rusalka pondweed than for Lake Winiary pondweed. The total biogas yield for these plants was $8.05 \mathrm{~m}^{3} \cdot \mathrm{Mg}^{-1}$ for Rusalka pondweed and $3.19 \mathrm{~m}^{3} \cdot \mathrm{Mg}^{-1}$ for Winiary pondweed. Differences in the chemical composition of pondweed originating from different lakes were also found, which translated into differences in the amount of energy that could be obtained from plants from both stands.
\end{abstract}

Keywords: lake restoration; curly-leaf pondweed; biomass; energy use; combustion; biogas; elemental analysis; proximate analysis; biochemical analysis

\section{Introduction}

As a result of human activities, many lakes in Poland and the world have become eutrophic [1-4]. Eutrophication of lakes is the phenomenon of increased abundance of organic matter in the reservoir, causing its fertilization [5-7]. The intensification of the eutrophication phenomenon in lakes manifests, among other factors, as increased phytoplankton bloom [8,9], development of submerged vegetation $[10,11]$ and decreased water transparency $[12,13]$. The process of eutrophication of lakes, its causes and effects, and ways to counteract it have been widely described in limnological literature [14-18].

A clear deterioration in the state of lake cleanliness has occurred in the last 30 years as a consequence of agricultural development (especially due to the use of fertilizers and the expansion of livestock production), tourism development and local industry development $[19,20]$. Eutrophication is ranked among the greatest threats to biodiversity in freshwater bodies of water [21-23]. More than 85\% of the lakes surveyed in recent years have phosphorus concentrations and transparency characteristic of eutrophic reservoirs. 
Many recent publications have indicated the deterioration of water quality in Poland [24-27] and worldwide $[28,29]$. Protection of lakes consists of finding a way to slow down, halt or even reverse the degradation processes or remove their negative consequences [30-32]. The basic way to protect water quality is to reduce or eliminate the sources of their supply of biogens [33-36].

Unfortunately, some water bodies have reached a high stage of degradation and thus it is necessary to introduce appropriate restoration methods [24-26,37]. Eutrophication of waters promotes overgrowth of water reservoirs. This is a negative phenomenon because it promotes their further eutrophication [38-40]. One way to prevent water decline is to bring fresh water from rivers [41]. However, this method is rarely feasible, as waters flowing from the catchment are often more polluted than lake waters [42-44]. However, it is possible to dispose of aquatic vegetation to reduce the nutrients in the water. For this purpose, it is possible to use special machines to mow and remove the vegetation outside the lake basin. The vegetation extracted from the lake needs to be managed. Among the different methods of biomass management, it is possible to use it in combustion or biomethane fermentation processes $[45,46]$. The macrophytes growing throughout the lake basin include curlyleaf pondweed.

Curly-leaf pondweed (Potamogeton crispus L.), also known as redweed, is a perennial in the pondweed family. It belongs to the useful aquatic plants. It resembles seaweed in appearance. It is fully frost-hardy. The place of its occurrence is still water bodies in both hemispheres [47-49]. In Poland, it is listed as a fairly common plant. It grows in the elodeid zone at a depth of 1 to $3 \mathrm{~m}$. It is a partly evergreen plant. It has thin and creeping stems. It grows to a height of 30 to $200 \mathrm{~cm}$. The leaves of the knotweed are submerged in water. Their length is up to $10 \mathrm{~cm}$. The leaves are characterized by a wavy edge. Their color ranges from light green to brown-green with a visible red stripe along the middle nerve. The flower of the plant is hermaphroditic. The spike of the plant has up to four petals and a green color, and protrudes above the water surface. The flowering period is from May to September/October. The fruit are nuts with wings and a long beak [50]. It is used for planting mainly in ponds and aquariums, as it oxygenates the water and removes nitrates. The plant does not have high requirements. The substrate can be sandy loam, gravel, clay, mineral, mineral-organic or organic. The preferred water hardness is $8-15^{\circ}(\mathrm{pH}$ 7.0-7.8). The maximum temperature is $22^{\circ} \mathrm{C}$. The pondweed reproduces vegetatively, from cuttings and offshoots appearing on the shoots [51]. Curly-leaf pondweed is a plant that helps to clean up lakes, and it has been proved that Potamogeton crispus can tolerate high doses of PAHs (polycyclic aromatic hydrocarbons). Moreover, in one study, the authors showed that the plant is further stimulated by the phenanthrene and pyrene found in sediments. The removal of PAHs (polycyclic aromatic hydrocarbons) is also improved by pondweed [52]. The main problem is the amount of pondweed that exists in the water body. After flowering, the plant dies, supplying the water body with the organic matter it previously cleared it of. To prevent this, the plant must be mown and the stems harvested. Reports of the mass occurrence of curly-leaf pondweed on lakes in Gniezno (Winiary) and Poznan (Rusalka) appeared in 2015-2017. This was mainly a result of a warm summer, winter and spring. In the case of undesirable plants on the lake, the only way to get rid of them sustainably is to mow them. This study presents solutions to manage the plants for energy purposes. The available options for the energetic use of plants include combustion to obtain thermal energy, and anaerobic digestion to obtain biomethane, hydrothermal liquefaction, pyrolysis. Each of these processes has its advantages and disadvantages. Methane fermentation, for example, is a clean process which allows one to obtain energy from organic matter and to leave mineral components in the digestate, which can be used as fertilizer, but it requires special installations [53]. Combustion requires as low a moisture content as possible [54]. Hydrothermal liquefaction, on the other hand, can alternatively be used to produce useful high-energy-density biocrude, biochar, etc. However, the HTL process requires high energy inputs and thus may not be energy-beneficial [55]. Similar advantages and disadvantages apply to the pyrolysis process, which requires the 
use of appropriate installations with a relatively high cost and requires significant energy inputs [56].

\section{Materials and Methods}

Lake Rusalka occupies an area of 36.7 ha. The maximum depth is $9.0 \mathrm{~m}$ and the average depth is $1.9 \mathrm{~m}$. The length of the shoreline is $3300 \mathrm{~m}$. The total catchment area is $25.1 \mathrm{~km}^{2}$. The direct catchment area is $90 \%$ forest and the rest is meadows. Lake Rusalka is very susceptible to degradation [57]. Lake Winiary is the largest of the lakes located in Gniezno. It lies to the northeast of the town center. Its surface area is $18.1 \mathrm{ha}$, and the maximum depth of the lake is $4.2 \mathrm{~m}$ (according to data from the Gniezno City Hall). Before this research, the curly-leaf pondweed was mown with a water mower to a depth of $0.5 \mathrm{~m}$ below the water level. Thanks to this treatment, the curly-leaf pondweed did not bloom and, as a consequence, no organic matter entered the lake. Plant samples in $20 \mathrm{~L}$ containers from both water bodies were transported to the University of Life Sciences. It was then dried using solar radiation. Finally curly-leaf pondweed from Lake Rusalka and Lake Winiary was cut into $1 \mathrm{~cm}$ pieces. Plants were subjected to chemical, technical and elemental analyses. In order to analyze the methods of energetic utilization, the studies were limited to plant combustion and the use of plants for a methane fermentation process. Selected technologies of biomass utilization are currently the most widespread and known in Poland and Europe [58]. For this purpose, it was decided to study the heat of combustion and to determine the calorific value, and to study the biogas yield of pondweed from the two mentioned lakes.

\subsection{Proximate Analysis}

Proximate analysis studies were performed using the TGA701 automated thermogravimetric analyzer. The measurement involved heating the sample to temperatures specified according to the standard while measuring the mass loss [59]. For biomass testing, ASTM E1131-08(2014) [60] was used to describe the steps involved in the thermogravimetric analysis performed with an automatic analyzer. The moisture content was determined by heating the sample to $105-110{ }^{\circ} \mathrm{C}$ and evaporating it. Determination of the volatile content was performed by heating the samples, placed in covered dishes, to a temperature of $850 \pm 15^{\circ} \mathrm{C}$ for about $7 \mathrm{~min}$. The biomass sample was then incinerated at $550{ }^{\circ} \mathrm{C}$.

\subsection{Biochemical Analysis}

The standard methods applied in analyses of plant biomass were used to test the chemical composition of the curly-leaf pondweed. The extractive content was determined according to Soxhlet (TAPPI-T $204 \mathrm{~cm}-07$ ) by using 96\% ethanol [61]. The content of cellulose was analyzed by Seifert's method. For this purpose, a mixture of acetylacetone and dioxane at an acidic $\mathrm{pH}$ was used [62].

Determination of lignin content by the Tappi method used $72 \%$ sulfuric acid (TAPPI-T $222 \mathrm{~cm}-06$ ) [63]; For the holocellulose content estimation, sodium chlorite was used (TAPPIT 9 wd-75) [64]. The theoretical content of hemicellulose was calculated mathematically as the difference between the holocellulose and cellulose contents. For the analysis of the amount of ash, the DIN 51731 standards were used [65]. According to the standard, the results were calculated in relation to the dry mass of the raw material, and the average of the 3 measurements was calculated. For determination of the moisture content the oven-dry method was used. The drying process was performed at a temperature of $103 \pm 2{ }^{\circ} \mathrm{C}$. The difference between the weighed values did not exceed $0.01 \%$.

Chemical analysis of the studied raw materials was performed courtesy of the Institute of Wood Chemical Technology at the Poznan University of Life Sciences. The research included analyses of the content of extractive substances, lignin, cellulose and holocellulose. Determination of the extractable substance content was based on extraction of resins, waxes and fatty acids from the tested material with ethyl alcohol. The extracted samples were suitable for further determination. 
The determination of lignin content involved dissolving insoluble carbohydrate compounds in sulfuric acid to form soluble sugars. The remaining lignin was then separated by sieving through crucibles so that its mass could be determined.

The determination of cellulose content was based on its separation by dissolving the lignin and other substances contained in the wood with a mixture of acetylacetone and dioxane, acidified with hydrochloric acid.

Holocellulose was extracted by delignification with sodium chlorite in the presence of glacial acetic acid.

\subsection{Elemental Analysis}

Elemental composition analyses were carried out using automatic CHN628 and 628S elemental analyzers at the Department of Power and Transport Means at the University of Life Sciences in Lublin.

Examination of the content of carbon, hydrogen and nitrogen using the CHN628 analyzer consisted of the combustion of a material sample of $0.1 \mathrm{~g}$ placed in a foil capsule, leading to complete oxidation of the abovementioned elements to carbon dioxide $\left(\mathrm{CO}_{2}\right)$, water $\left(\mathrm{H}_{2} \mathrm{O}\right)$ and nitrogen oxide $\left(\mathrm{NO}_{\mathrm{x}}\right)$, respectively. The carbon and hydrogen content were determined using separate NDIR (non-dispersive infrared) cells based on the contents of water vapor and carbon dioxide. Nitrogen oxides $\left(\mathrm{NO}_{\mathrm{x}}\right)$ were reduced to pure nitrogen by using a copper-filled reduction tube. Carbon dioxide and water were removed from the gas portion. The nitrogen content was determined using a thermoconductive (TC) cell [66].

Determination of the sulfur content was performed using the $628 \mathrm{~S}$ module. The analysis involved placing a $0.2 \mathrm{~g}$ sample in a special crucible, which was then introduced into a furnace where it was burned in an oxygen atmosphere at $1350^{\circ} \mathrm{C}$. The sulfur in the sample was released in the form of sulfur dioxide $\left(\mathrm{SO}_{2}\right)$ and its content was determined using the IR infrared detection objective [66].

\subsection{Testing of Combustion Heat and Determination of the Calorific Value of Potamogeton crispus}

The moisture content of fresh Potamogeton crispus was determined prior to the study of the combustion heat. Due to the high water content, the Potamogeton crispus was dried to an air-dry dry state, enabling the determination of combustion heat and calorific value. Natural factors were used for drying. The date of the knotweed harvest was in the summer months, which meant that it was possible to dry the knotweed spontaneously by leaving it exposed to the atmospheric factors of temperature and wind. Four days with temperatures slightly above $20^{\circ} \mathrm{C}$ and no rainfall were sufficient to obtain humidity below $10 \%$. Samples of Potamogeton crispus were ground for analysis and then were sieved to obtain a representative sample with a $0.2 \mathrm{~mm}$ fraction. The combustion heat tests were carried out at the Institute of Chemical Wood Technology using a KL-12Mn2 computer calorimeter based on DIN 51900-2:2003-05 standards [67]. The test involved complete combustion of the sample in an oxygen atmosphere in a calorimetric bomb immersed in a water jacket, with simultaneous measurement of the rise in temperature of the water. To determine the calorific value, it was necessary to determine the moisture content. This parameter was determined using the dryer-weight method according to ISO 18134-3:2015 [68].

\subsection{Testing of Biogas Yield of Potamogeton Crispus}

A biogas efficiency study of Potamogeton was carried out in the Chemical Analysis Laboratory at the Institute of Biosystems Engineering. The study used slurry from a cattle farming farm and Potamogeton crispus. The materials used to produce the mixture were tested for dry matter and organic matter content.

The biogas yield tests were carried out in accordance with Norm DIN 38414-8 [69,70] in a multi-chamber fermentation station (Figure 1), based on a eudiometric system that stored the biogas generated in a fermentation tank with a capacity of $1 \mathrm{dm}^{3}$. A measurement 
station for biomethane, carbon dioxide, hydrogen sulfide and oxygen was used for the biogas gas concentration test (Alter Bio MSMR 16).

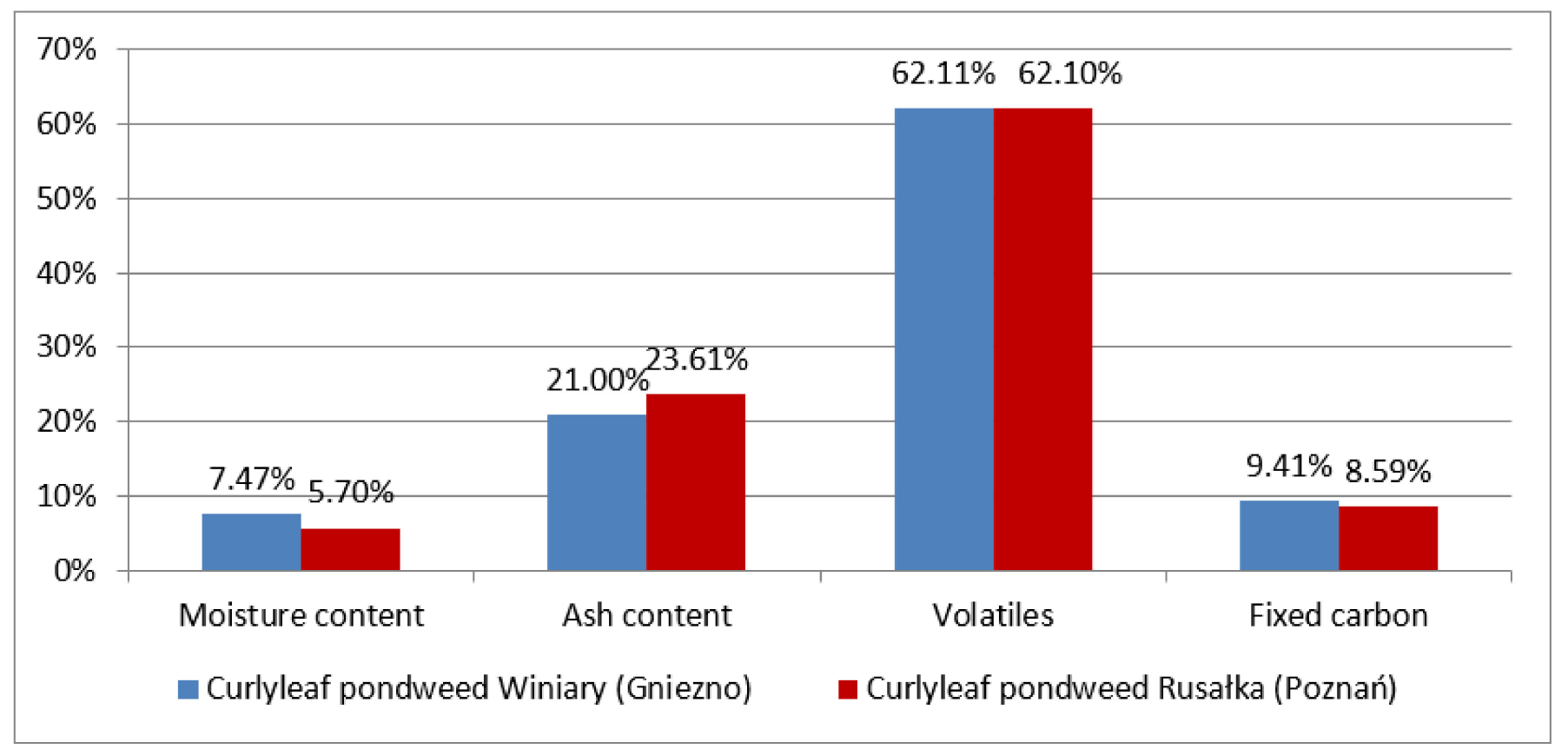

Figure 1. Proximate analysis results for the curly-leaf pondweed samples analyzed.

The concentration and volume of gas evolved were measured at $24 \mathrm{~h}$ intervals. For statistical purposes, mixtures with the same composition were placed in three identical biofermenters. In order to measure the composition of the biogas produced, measuring heads of the series MG-72 and MG-73 series were used with a measuring range of 0-100\% volume and a measuring resolution of $0.1 \mathrm{ppm}$ to $1 \%$ volume.

The parameter that was evaluated was the volume of generated biogas and the cumulative value. During the study, the processing temperature was $36^{\circ} \mathrm{C}$.

The object was a mixture of solid and liquid substrates that was subjected to anaerobic degradation. The study planned three repetitions of the tests of the biogas efficiency of the mixture of bovine slurry and Potamogeton crispus. Average results were converted into volume units of separated biogas $\left(\mathrm{m}^{3}\right)$ per unit of fresh matter, dry matter and dry organic matter.

\section{Results}

Before the studies of the chemical composition of curly-leaf pondweed, the moisture content of the fresh matter was determined. For curly-leaf pondweed from Lake Winiary (Gniezno), the moisture content was determined as $91.44 \%$, and for pondweed from Lake Rusalka (Poznan), it was $86.13 \%$. Further analyses were performed, according to the current standards, for samples in an air-dry state.

\subsection{Proximate Analysis}

The air-dry samples submitted for proximate analysis (Figure 1) showed a moisture content of $7.47 \%$ (Lake Winiary pondweed) and 5.70\% (Lake Rusalka pondweed). There was an almost identical volatile content of $62.10 \%$ for both types of pondweed. Slight differences in ash and bound carbon contents were observed. For the Lake Winiary pondweed, the ash content was determined as $21.00 \%$, and for the Lake Rusalka pondweed, it was $23.61 \%$. The bound carbon content was $9.41 \%$ (Winiary) and $8.59 \%$ (Rusalka). 


\subsection{Biochemical Analysis}

The samples of pondweed subjected to chemical analysis (Figure 2) showed significant differences among individual parameters determined as a result of this analysis. Pondweed from Lake Winiary contained a higher content of extractives $(9.25 \%$, Winiary; $7.69 \%$, Rusalka), lignin (25.15\%, Winiary; $21.14 \%$, Rusalka) and cellulose (32.13\%, Winiary; $23.67 \%$, Rusalka). On the other hand, the pondweed from Lake Rusalka had a much higher content of hemicellulose $(15.02 \%)$, while the content of this component for the pondweed from Lake Winiary was only $3.39 \%$.

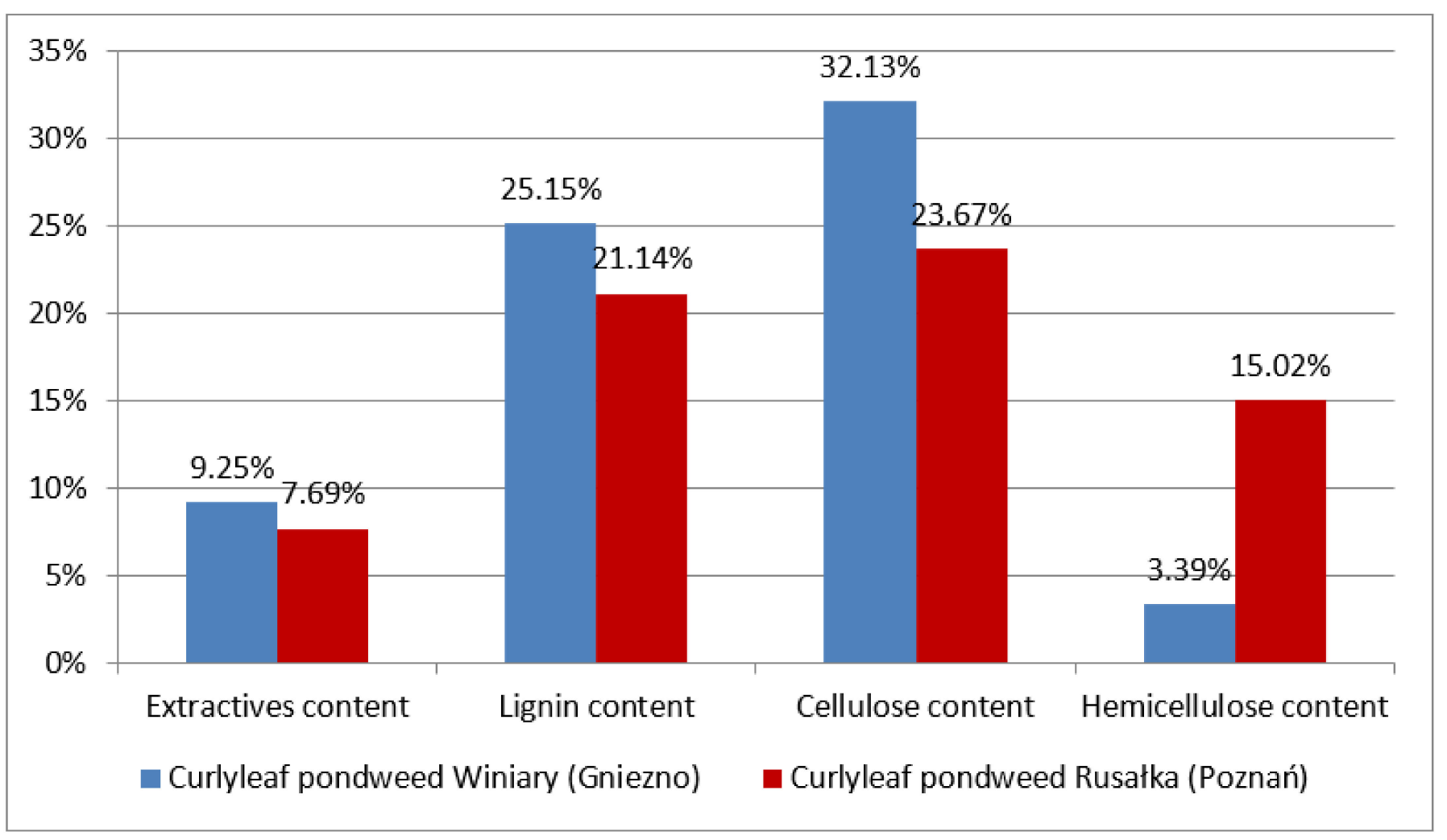

Figure 2. Chemical analysis results for the curly-leaf pondweed samples analyzed.

\subsection{Elemental Analysis}

As a result of the elemental analysis (Figure 3), differences were found in the carbon content, which was $35.84 \%$ for the pondweed from Lake Winiary, while for the pondweed from Lake Rusalka, it was lower and amounted to $28.70 \%$. Significant differences were also found in hydrogen $(5.33 \%$, Winiary; $3.87 \%$, Rusalka), nitrogen $(2.64 \%$, Winiary; $1.27 \%$, Rusalka) and oxygen (55.67\%, Winiary; $65.71 \%$, Rusalka) contents. In the case of sulfur content, pondweed from Lake Winiary contained $0.52 \%$, while the content of this component for pondweed from Lake Rusalka was $0.45 \%$. 


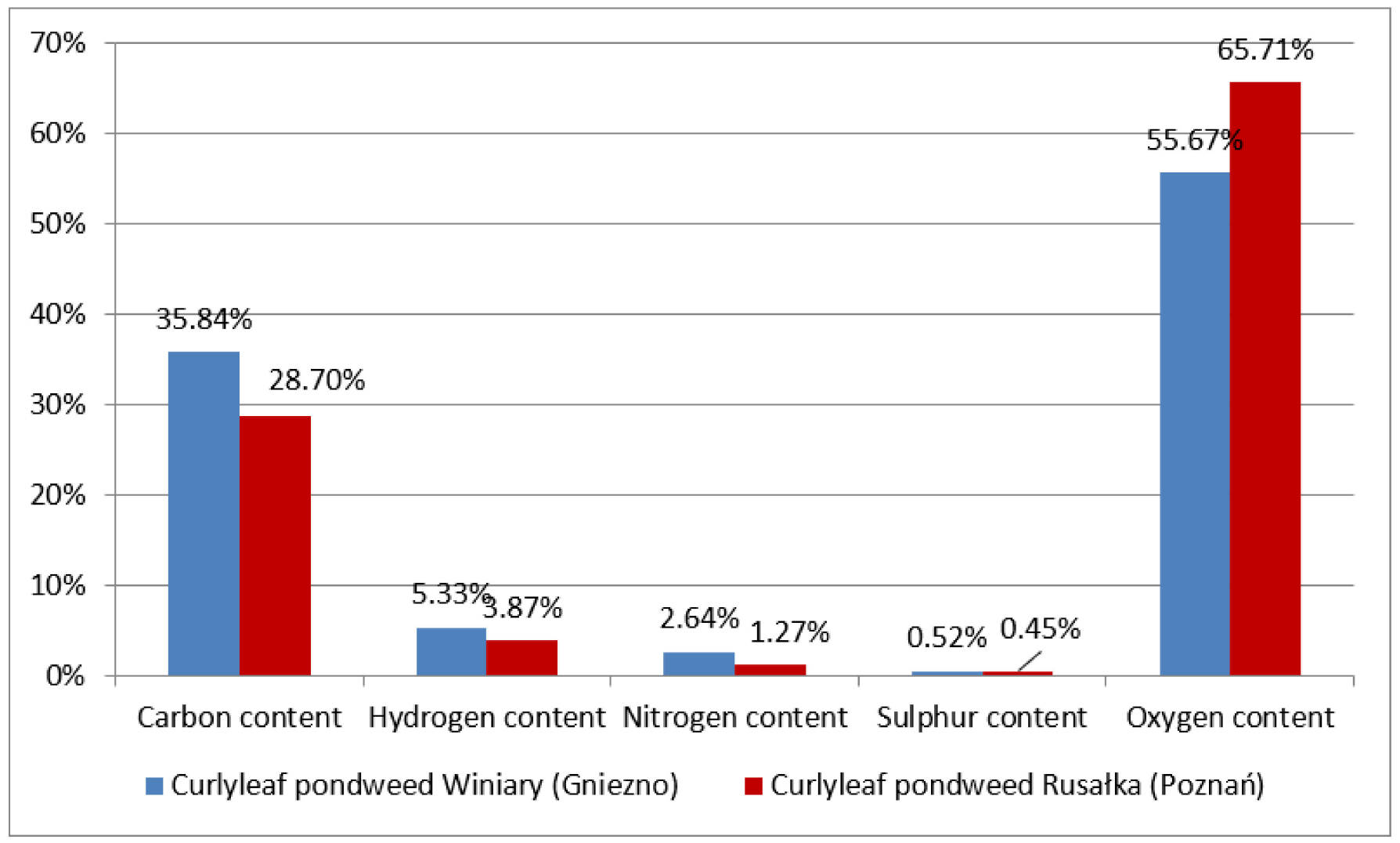

Figure 3. Elemental analysis results for the curly-leaf pondweed samples analyzed.

\subsection{Heat of Combustion and Calorific Value of Pondweed}

The results of calorimetric examination (Figure 4) showed that in case of curly-leaf pondweed coming from Lake Winiary (Gniezno), it was possible to obtain much more energy than in the case of pondweed from Lake Rusalka (Poznañ). The calorific value of curly-leaf pondweed from Lake Winiary was $13.95 \mathrm{MJ} \cdot \mathrm{kg}^{-1}$, while for the Lake Rusalka pondweed, it was $9.10 \mathrm{MJ} \cdot \mathrm{kg}^{-1}$. The calorific value of Lake Winiary pondweed at $7.47 \%$ moisture content was $9.10 \mathrm{MJ} \cdot \mathrm{kg}^{-1}$, while for Lake Rusalka pondweed at $5.70 \%$ moisture content, it was $7.80 \mathrm{MJ} \cdot \mathrm{kg}^{-1}$. 


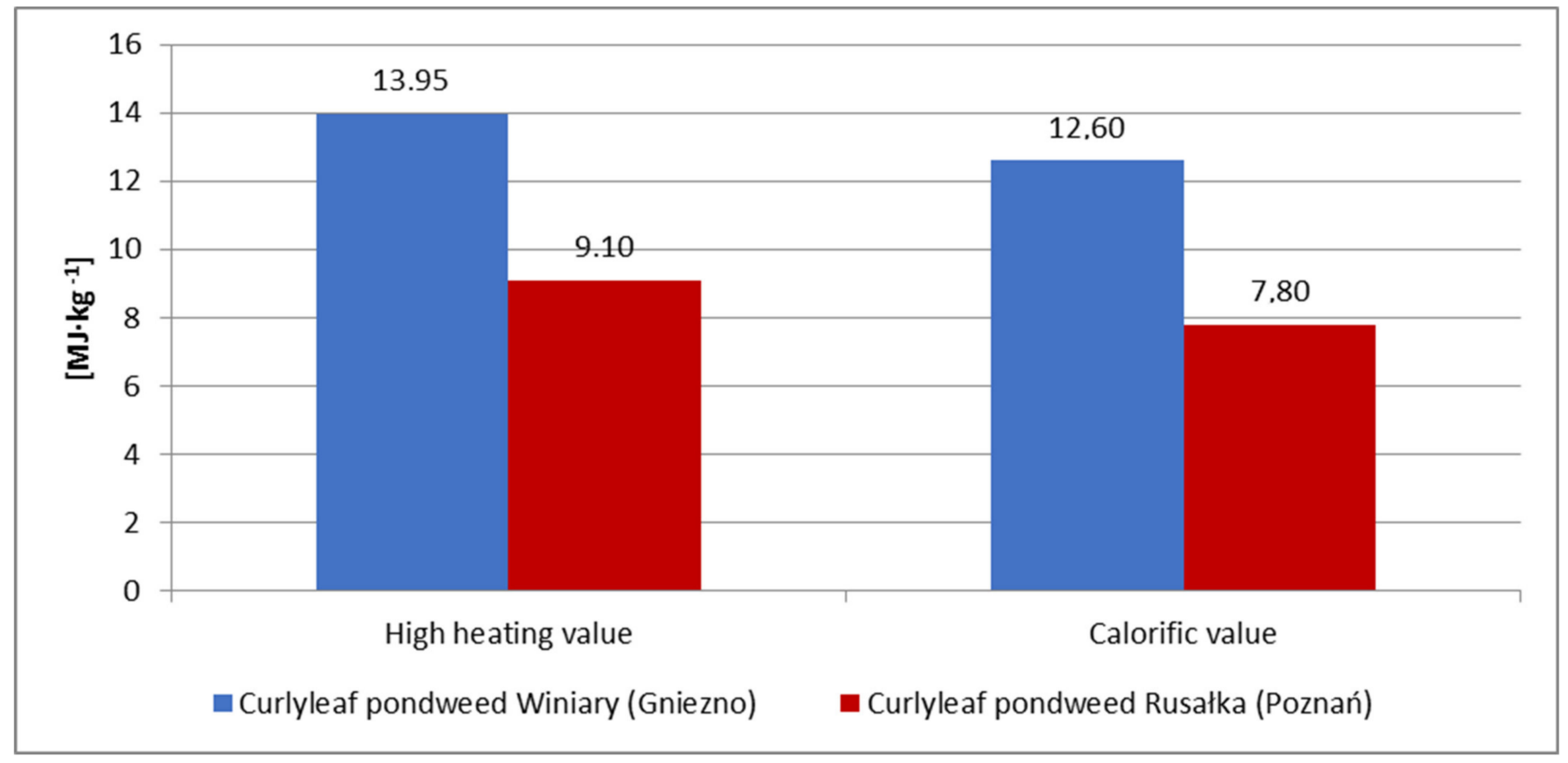

Figure 4. Combustion heat and calorific value of curly-leaf pondweed from Lake Winiary (Gniezno) and Lake Rusalka (Poznań).

\subsection{Biogas Yield of Curly-Leaf Pondweed}

The substrate samples prepared from Lake Rusalka had an average moisture content of $56.37 \%$. The data of the mixture used for the study are presented in Table 1.

Table 1. Parameters of the slurry and pondweed mixture from Lake Rusalka.

\begin{tabular}{ccccc}
\hline Component & $\begin{array}{c}\text { Fresh Matter Used for } \\
\text { Testing }\end{array}$ & $\begin{array}{c}\text { Proportion of } \\
\text { Components in the } \\
\text { Sample }\end{array}$ & Dry Matter Content & $\begin{array}{c}\text { Dry Matter in the } \\
\text { Sample }\end{array}$ \\
\cline { 2 - 5 } & $\mathbf{g}$ & $\mathbf{\%}$ & 1.25 & $\mathbf{g}$ \\
\hline Slurry & 450 & 75 & 13.75 & 5625 \\
\hline Curly-leaf pondweed & 150 & 25 & - & 20,805 \\
\hline TOTAL & 600 & 100 & & 26,430 \\
\hline
\end{tabular}

The samples that were prepared for the biomethane fermentation experiment of the substrate coming from Lake Winiary had an average moisture content of $77.41 \%$; its parameters are presented in Table 2.

Table 2. Parameters of the slurry and pondweed mixture from Lake Winiary.

\begin{tabular}{ccccc}
\hline Component & $\begin{array}{c}\text { Fresh Matter Used for } \\
\text { Testing }\end{array}$ & $\begin{array}{c}\text { Proportion of } \\
\text { Components in the } \\
\text { Sample }\end{array}$ & Dry Matter Content & $\begin{array}{c}\text { Dry Matter in the } \\
\text { Sample }\end{array}$ \\
\cline { 2 - 5 } & $\mathbf{g}$ & $\mathbf{\%}$ & 1.25 & $\mathbf{9}$ \\
\hline Slurry & 450 & 25 & 8.56 & 5625 \\
\hline TOTAL & 150 & 100 & - & 12,840 \\
\hline
\end{tabular}


Measurements of the individual gas components $\left(\mathrm{CH}_{4}, \mathrm{CO}_{2}, \mathrm{H} 2_{\mathrm{S}}, \mathrm{O}_{2}\right)$ were observed throughout the experiment. The release was varied. Very characteristic was the decrease in $\mathrm{H}_{2} \mathrm{~S}$ at Day 5 for all samples.

For curly-leaf pondweed from Lake Rusalka, it decreased from 306 ppm on Day 4 to a level of $10 \mathrm{ppm}$ on Day 5 of the experiment, while for the other substrate, it decreased to $19 \mathrm{ppm}$ on Day 4 . The collected biomethane fermentation results are summarized in Table 3.

Table 3. Results of the measurements of individual components during biomethane fermentation of curly-leaf pondweed from Lake Rusalka and Lake Winiary.

\begin{tabular}{|c|c|c|c|c|c|c|c|c|c|c|}
\hline \multirow[t]{2}{*}{ Day } & \multicolumn{5}{|c|}{ Curly-Leaf Pondweed from Lake Rusalka } & \multicolumn{5}{|c|}{ Curly-Leaf Pondweed from Lake Winiary } \\
\hline & $\begin{array}{c}\text { Volume } \\
\text { per } \\
\text { Volatile } \\
\text { Matter } \\
\left(\mathrm{dm}^{3} \cdot \mathbf{k g}^{-1}\right)\end{array}$ & $\begin{array}{l}\mathrm{CH}_{4} \\
(\%)\end{array}$ & $\begin{array}{l}\mathrm{CO}_{2} \\
(\%)\end{array}$ & $\begin{array}{c}\mathrm{H}_{2} \mathrm{~S} \\
(\mathrm{ppm})\end{array}$ & $\begin{array}{c}\mathrm{O}_{2} \\
(\%)\end{array}$ & $\begin{array}{c}\text { Volume } \\
\text { per } \\
\text { Volatile } \\
\text { Matter } \\
\left(\mathrm{dm}^{3} \cdot \mathrm{kg}^{-1}\right)\end{array}$ & $\begin{array}{l}\mathrm{CH}_{4} \\
(\%)\end{array}$ & $\begin{array}{c}\mathrm{CO}_{2} \\
(\%)\end{array}$ & $\begin{array}{c}\mathrm{H}_{2} \mathrm{~S} \\
(\mathrm{ppm})\end{array}$ & $\begin{array}{l}\mathrm{O}_{2} \\
(\%)\end{array}$ \\
\hline 1 & 0,00 & 0 & 0 & 0 & 0 & 0,00 & 0 & 0 & 0 & 0 \\
\hline 2 & 27.08 & 20.0 & 47 & 100 & 6.8 & 12.72 & 20.0 & 47 & 90 & 6.8 \\
\hline 3 & 37.13 & 38.0 & 58 & 306 & 3.0 & 37.78 & 45.1 & 52 & 304 & 1.9 \\
\hline 4 & 28.75 & 46.2 & 49 & 10 & 3.8 & 13.49 & 44.7 & 51 & 29 & 3.3 \\
\hline 5 & 31.83 & 72.5 & 23 & 40 & 3.5 & 20.05 & 71.0 & 24 & 15 & 4.0 \\
\hline 6 & 55.00 & 71.7 & 24 & 50 & 3.3 & 11.57 & 91.0 & 0 & 150 & 8.0 \\
\hline 7 & 12.56 & 81.9 & 13 & 80 & 4.1 & 14.26 & 65.9 & 26 & 180 & 7.1 \\
\hline 8 & 18.70 & 62.1 & 31 & 150 & 5.9 & 10.79 & 62.1 & 31 & 290 & 5.9 \\
\hline 9 & 8.38 & 58.0 & 37 & 350 & 4.0 & 3.86 & 58.0 & 37 & 350 & 4.0 \\
\hline 10 & 7.26 & 56.0 & 37 & 493 & 6.0 & 8.48 & 57.9 & 35 & 493 & 6.1 \\
\hline 11 & 3.91 & 60.6 & 36 & 492 & 2.4 & 3.47 & 60.7 & 34 & 492 & 4.3 \\
\hline 12 & 8.38 & 63.4 & 34 & 491 & 1.6 & 3.47 & 63.7 & 33 & 491 & 2.3 \\
\hline 13 & 5.58 & 62.4 & 35 & 465 & 1.6 & 1.54 & 64.0 & 33 & 422 & 2.0 \\
\hline 14 & 9.21 & 61.4 & 36 & 439 & 1.6 & 0.77 & 64.4 & 33 & 354 & 1.6 \\
\hline 15 & 4.47 & 70.5 & 23 & 264 & 5.5 & 0.39 & 67.0 & 30 & 300 & 2.0 \\
\hline 16 & 2.79 & 69.6 & 26 & 326 & 3.4 & 0.77 & 67.4 & 29 & 292 & 2.6 \\
\hline 17 & 2.51 & 70.1 & 26 & 231 & 2.9 & 1.54 & 70.1 & 26 & 231 & 2.9 \\
\hline 18 & 0.84 & 71.0 & 25 & 169 & 3.0 & 0.39 & 71.0 & 25 & 169 & 3.0 \\
\hline 19 & 0.84 & 69.0 & 26 & 160 & 1.8 & 0.00 & 72.4 & 24 & 160 & 2.6 \\
\hline 20 & 3.07 & 65.0 & 27 & 158 & 1.7 & 1.16 & 65.0 & 22 & 159 & 2.0 \\
\hline 21 & 1.68 & 60.0 & 30 & 150 & 1.6 & 1.16 & 58.0 & 20 & 150 & 1.0 \\
\hline
\end{tabular}

As the fermentation process proceeded, the volume of biogas released in the hydrophase changed (Figure 5). The highest values occurred in the first week for both substrates. After this period, the volume successively decreased. A significant difference could be seen in the instantaneous course for pondweed from Gniezno and Poznań. The cumulative biogas yield for Lake Rusalka pondweed with respect to volatile matter was $269.96 \mathrm{dm}^{3} \cdot \mathrm{kg}^{-1}$ On the other hand, for the pondweed from Lake Winiary, the biogas productivity in relation to volatile matter was $147.65 \mathrm{dm}^{3} \cdot \mathrm{kg}^{-1}$. The pondweed from Lake Rusalka had a maximum instantaneous yield of $0.99 \mathrm{dm}^{3}$. The maximum daily yield for the biogas from Lake Winiary was two times lower. 


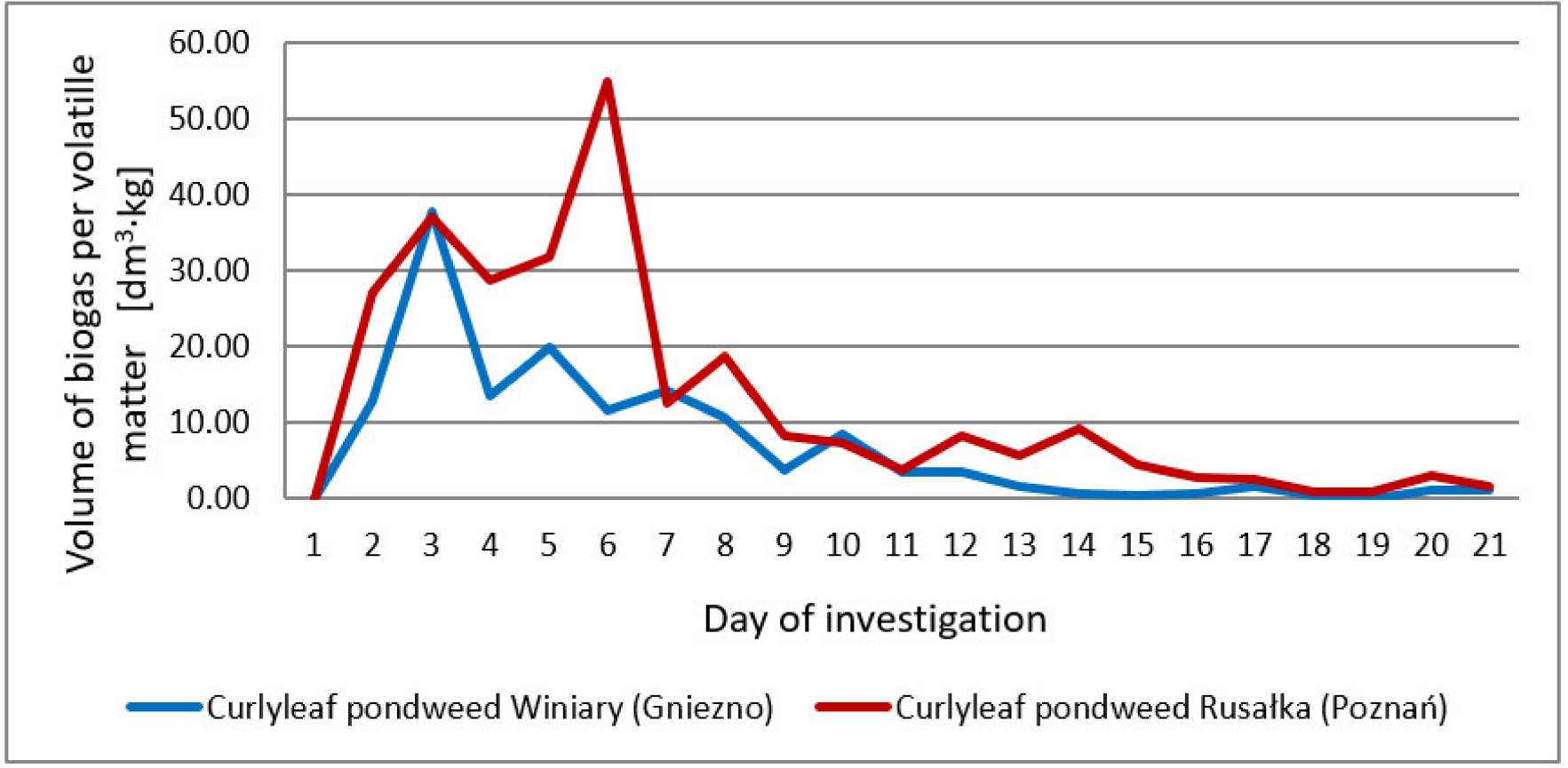

Figure 5. Graph of instantaneous biogas yield for curly-leaf pondweed per volatile matter.

The most important value in terms of energy was the concentration of biomethane in the resulting biogas. Figure 6 shows a graph of the $\mathrm{CH}_{4}$ concentration in the resulting biogas expressed as a percentage. The average production for both substrates was about $60 \%$.

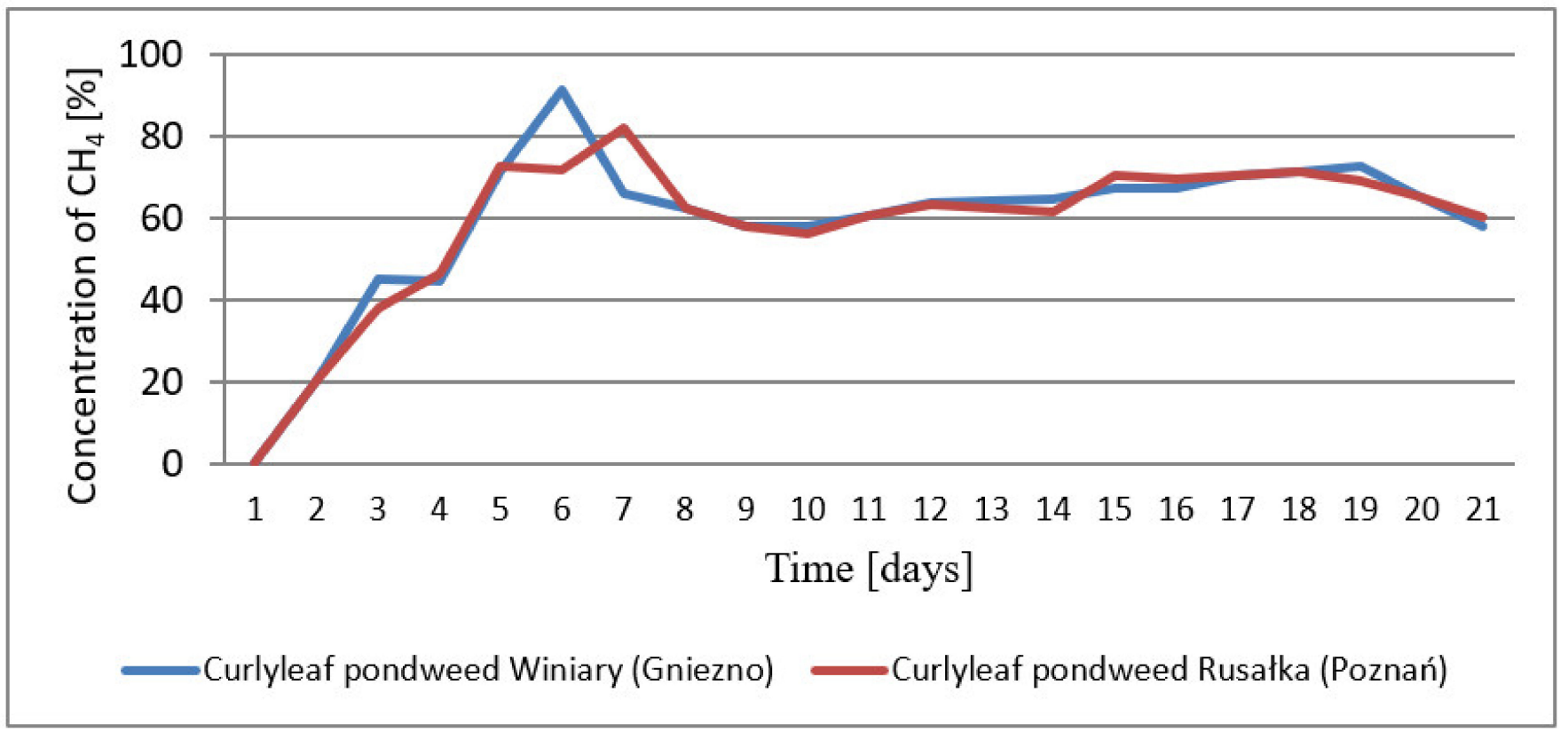

Figure 6. Graph of biomethane concentration in biogas.

\section{Conclusions}

In this study, pondweed from two different lakes was examined for its utilization as energy potential. Tests were carried out to assess the usefulness of the plants for combustion 
and use as input material to a fermenter. The selected technologies of biomass utilization are currently the most widespread and known in Poland and Europe [58].

On the basis of the conducted studies, it was determined that the use of curly-leaf pondweed for energy purposes is possible, both in the combustion method and in the process of biomethane fermentation. The differences in the chemical composition of curlyleaf pondweed from different water bodies were also demonstrated, which translate into differences in the amount of energy possible to be obtained from plants from both sites.

The calorimetric study showed the possibility of obtaining more energy from curlyleaf pondweed coming from Lake Rusalka. The heat of combustion of these plants was 13.95 MJ $\cdot \mathrm{kg}^{-1}$ for pondweed from Lake Winiary and $9.10 \mathrm{MJ} \cdot \mathrm{kg}^{-1}$ for pondweed from Lake Rusalka. The calorific value of these plants was $12.60 \mathrm{MJ} \cdot \mathrm{kg}^{-1}$ for Lake Winiary pondweed and $7.80 \mathrm{MJ} \cdot \mathrm{kg}^{-1}$ for Lake Rusalka pondweed. On average, the efficiency of a biomass boiler is assumed to be $85 \%$. Using this assumption, it can be assumed that for pondweed from Lake Winiary, $10.75 \mathrm{MJ} \cdot \mathrm{kg}^{-1}$ could be obtained; for pondweed from Lake Rusalka, $6.63 \mathrm{MJ} \cdot \mathrm{kg}^{-1}$ could be obtained. Both results, due to low values, indicate the possibility of using pondweed as a fuel material only in co-combustion.

However, the use of milkweed as biomass for combustion requires it to be dried first. Usually, the drying process is energy-intensive and poses a fire risk [71]. In the case of pondweed, this was easily avoided. Naturally dried pondweed was used for the calorimetric study. It was exposed to the weather immediately after harvesting. Due to the fact that the harvest date was in the summer months, obtaining a satisfactory moisture content for burning was not an overly time-consuming process. Four warm, rainless days with daytime air temperatures slightly above $20{ }^{\circ} \mathrm{C}$ were sufficient to obtain a humidity of less than $10 \%$. In the case of the biogas yield studies, significantly higher biogas production was observed for Lake Rusalka pondweed than for Lake Winiary pondweed. The total biogas yield for these plants was $8.05 \mathrm{~m}^{3} \cdot \mathrm{Mg}^{-1}$ for pondweed from Lake Rusalka and $3.19 \mathrm{~m}^{3} \cdot \mathrm{Mg}^{-1}$ for pondweed from Lake Winiary. The total biogas yield for these plants for volatile matter was $269.68 \mathrm{~m}^{3} \cdot \mathrm{Mg}^{-1}$ for pondweed from Lake Rusalka and $147.26 \mathrm{~m}^{3} \cdot \mathrm{Mg}^{-1}$ for pondweed from Lake Winiary. It should be noted that in the case of pondweed from Lake Rusalka, the biogas yield was too low for a methane fermentation process based solely on its use to be viable.

These differences in energy yield can be explained by the results of the chemical composition analyses, both elemental and chemical. The pondweed from Lake Winiary was characterized by a higher content of carbon and hydrogen, which resulted in higher values for the heat of combustion and calorific value. The Lake Rusalka pondweed showed a higher biogas yield. The reason may be the higher lignin content in the case of the plant from Lake Winiary. The carbon contained in lignin is barely accessible for biomethane bacteria, so the decomposition of lignin, and thus the production of biomethane from carbon, takes place at a very low level. In the plants from Lake Winiary, a higher content of cellulose can be observed. This compound is easily decomposable by biomethane bacteria, but it is often included in the lignocellulosic complex, where it is barely accessible to them.

Author Contributions: Conceptualization, M.H., A.O., E.O., B.W. and. G.Z.; Data curation, M.H., A.O. and E.O.; Formal analysis, M.H. and A.O.; Investigation M.H., A.O. and E.O.; Methodology M.H., B.W. and G.Z.; Resources, M.H., A.O., E.O., B.W. and G.Z.; Supervision, M.H.; Validation, M.H., A.O., E.O., B.W. and G.Z.; Visualization, M.H., A.O. and E.O.; Writing—original draft, M.H., A.O., E.O., B.W. and G.Z.; Writing-review \& editing, M.H., A.O., E.O., B.W. and G.Z. All authors have read and agreed to the published version of the manuscript.

Funding: This research received no external funding.

Institutional Review Board Statement: Not applicable.

Informed Consent Statement: Not applicable.

Data Availability Statement: Not applicable. 
Acknowledgments: The publication was co-financed within the framework of the Ministry of Science and Higher Education programme as "Regional Initiative Excellence" in years 2019-2022, Project No. 005/RID/2018/19.

Conflicts of Interest: The authors declare no conflict of interest.

\section{References}

1. Harper, D.M. Eutrophication of Freshwaters: Principles, Problems and Restoration; Chapman and Hall: London, UK, 1992.

2. Kajak, Z. Eutrophication of Lakes; PWN: Warsaw, Poland, 2001. (In Polish)

3. Osuch, E.; Osuch, A.; Podsiadłowski, S.; Piechnik, L.; Chwirot, D. Project of coagulant dispenser in pulverization aerator with wind drive. J. Ecol. Eng. 2017, 18, 192-198. [CrossRef]

4. Wang, H.; Ma, M. Impacts of Climate Change and Anthropogenic Activities on the Ecological Restoration of Wetlands in the Arid Regions of China. Energies 2016, 9, 166. [CrossRef]

5. Podsiadłowski, S.; Gołdyn, R. Methods for sustainable lake restotation. Wielkop. Ecol. Bull. 2009. (In Polish)

6. Kowalczewska-Madura, K.; Dondajewska, R.; Gołdyn, R.; Kozak, A.; Messyasz, B. Internal Phosphorus Loading from the Bottom Sediments of a Dimictic Lake During Its Sustainable Restoration. Water Air Soil Pollut. 2018, 229, 280. [CrossRef] [PubMed]

7. Kowalczewska-Madura, K.; Gołdyn, R. Antropogenic changes in water quality in Swarzędzkie Lake (West Poland). Limnol. Rev. 2006, 6, 147-154.

8. Han, M.; Dong, C.; Ma, S.; Feng, C.; Lei, C.; Gu, Z.; Liu, X. Food Web Responses to a Cyanobacterial Bloom in a Freshwater Eutrophic Lake. Water 2021, 13, 1296. [CrossRef]

9. Rybacki, P.; Wolna-Maruwka, A.; Osuch, A.; Grześ, Z.; Niewiadomska, A. Seasonal Variability in Chemical and Microbiological Status of Bottom Sediments in Lake Rusałka at Removal of Cyanobacterial Blooms from its Surface. Pol. J. Environ. Stud. 2020, 29, 1323-1330. [CrossRef]

10. Meng, X.; Zhou, Y.; Sun, Z.; Ding, K.; Chong, L. Hydraulic Characteristics of Emerged Rigid and Submerged Flexible Vegetations in the Riparian Zone. Water 2021, 13, 1057. [CrossRef]

11. Rowan, G.; Kalacska, M. A Review of Remote Sensing of Submerged Aquatic Vegetation for Non-Specialists. Remote Sens. 2021, 13, 623. [CrossRef]

12. Bai, S.; Gao, J.; Sun, D.; Tian, M. Monitoring Water Transparency in Shallow and Eutrophic Lake Waters Based on GOCI Observations. Remote Sens. 2020, 12, 163. [CrossRef]

13. Podsiadłowski, S. Method of precise phosphorus in activation in lake waters. Limnol. Rev. 2008, 8, 3-8.

14. Lossow, K. Lake protection and restoration-Theory and practice. Ecological ideas. Sketches Ser. 1998, 13, 55-71. (In Polish)

15. Osuch, A.; Rybacki, P.; Osuch, E.; Adamski, M.; Buchwald, T.; Staszek, Ż. Assessment of the quality of waters of the Łomno lake. Inżynieria Ekol. 2016, 46, 24-30. [CrossRef]

16. Osuch, E.; Osuch, A.; Rybacki, P.; Przybylak, A. Analysis of the Theoretical Performance of the Wind-Driven Pulverizing Aerator in the Conditions of Góreckie Lake-Maximum Wind Speed Method. Energies 2020, 13, 502. [CrossRef]

17. Gołdyn, R.; Podsiadłowski, S.; Dondajewska, R.; Kozak, A. The sustainable restoration of lakes-towards the challenges of the water framework directive. Ecohydrol. Hydrobiol. 2014, 14, 68-74. [CrossRef]

18. Podsiadłowski, S.; Osuch, E.; Przybył, J.; Osuch, A.; Buchwald, T. Pulverizing aerator in the process of lake restotation. Ecol. Eng. 2018, 121, 99-103. [CrossRef]

19. Rosińska, J.; Kozak, A.; Dondajewska, R.; Gołdyn, R. Cyanobacteria blooms before and during the restoration process of a shallow urban lake. J. Environ. Manag. 2017, 198, 340-347. [CrossRef]

20. Rybacki, P.; Przygodziński, P.; Osuch, A.; Blecharczyk, A.; Walkowiak, R.; Osuch, E.; Kowalik, I. The Technology of Precise Application of Herbicides in Onion Field Cultivation. Agriculture 2021, 11, 577. [CrossRef]

21. Liu, M.; Ran, Y.; Peng, X.; Zhu, Z.; Liang, J.; Ai, H.; Li, H.; He, Q. Sustainable modulation of anaerobic malodorous black water: The interactive effect of oxygen-loaded porous material and submerged macrophyte. Water Res. 2019, 160, 70-80. [CrossRef]

22. Osuch, E.; Osuch, A.; Podsiadłowski, S.; Rybacki, P.; Mioduszewska, N. Use of Wind Energy in the Process of Lake Restoration. In Renewable Energy Sources: Engineering, Technology, Innovation; Wróbel, M., Jewiarz, M., Szlek, A., Eds.; Springer Proceedings in Energy; Springer: Cham, Switzerland, 2020; pp. 551-559.

23. Zhou, L.; Wang, X.; Zhang, X.; Zhao, Y.; Zhu, P.; Zhao, X.; Ligang, Z. Spatiotemporal Variations in Nitrogen and Phosphorus in a Large Man-Made Lake and Their Relationships with Human Activities. Water 2020, 12, 1106. [CrossRef]

24. Kozak, A.; Budzyńska, A.; Dondajewska-Pielka, R.; Kowalczewska-Madura, K.; Gołdyn, R. Functional Groups of Phytoplankton and Their Relationship with Environmental Factors in the Restored Uzarzewskie Lake. Water 2020, 12, 313. [CrossRef]

25. Rosińska, J.; Kozak, A.; Dondajewska, R.; Kowalczewska-Madura, K.; Gołdyn, R. Water quality response to sustainable restoration measures-Case study of urban Swarzędzkie Lake. Ecol. Indic. 2018, 84, 437-449. [CrossRef]

26. Kozak, A.; Gołdyn, R.; Dondajewska, R.; Kowalczewska-Madura, K.; Holona, T. Changes in Phytoplankton and Water Quality during Sustainable Restoration of an Urban Lake Used for Recreation and Water Supply. Water 2017, 9, 713. [CrossRef]

27. Osuch, A.; Osuch, E.; Podsiadłowski, S.; Rybacki, P. Analysis of Performance of the Wind-Driven Pulverizing Aerator Based on Average Wind Speeds in the Conditions of Góreckie Lake. Energies 2021, 14, 2796. [CrossRef]

28. Shang, W.; Jin, S.; He, Y.; Zhang, Y.; Li, J. Spatial-Temporal Variations of Total Nitrogen and Phosphorus in Poyang, Dongting and Taihu Lakes from Landsat-8 Data. Water 2021, 13, 1704. [CrossRef] 
29. Rose, V.; Rollwagen-Bollens, G.; Bollens, S.; Zimmerman, J. Effects of Grazing and Nutrients on Phytoplankton Blooms and Microplankton Assemblage Structure in Four Temperate Lakes Spanning a Eutrophication Gradient. Water 2021, $13,1085$. [CrossRef]

30. Dondajewska, R.; Kowalczewska-Madura, K.; Gołdyn, R.; Kozak, A.; Messyasz, B.; Cerbin, S. Long-Term Water Quality Changes as a Result of a Sustainable Restoration-A Case Study of Dimictic Lake Durowskie. Water 2019, 11, 616. [CrossRef]

31. Daus, M.; Koberger, K.; Koca, K.; Beckers, F.; Fernández, J.E.; Weisbrod, B.; Dietrich, D.; Gerbersdorf, S.; Glaser, R.; Haun, S.; et al. Interdisciplinary Reservoir Management-A Tool for Sustainable Water Resources Management. Sustainability 2021, 13, 4498. [CrossRef]

32. Osuch, E.; Osuch, A.; Podsiadłowski, S.; Rybacki, P.; Adamski, M.; Ratajczak, J. Assessment of the condition of the Samołęskie Lake waters. J. Ecol. Eng. 2016, 17, 108-112. [CrossRef]

33. Kajak, Z. Hydrobiologia-limnologia. Ekosystemy Wód Śródlądowych; Wydawnictwo Naukowe PWN: Warszawa, Poland, 1998.

34. Osuch, A.; Rybacki, P.; Podsiadłowski, S.; Przygodziński, P. System of precise dosing of coagulant in the pulverizing aerator powered by wind using fuzzy logic. Ecol. Eng. Environ. Technol. 2017, 18, 210-217. [CrossRef]

35. Demertzioglou, M.; Antonopoulou, E.; Voutsa, D.; Kozari, A.; Moustaka-Gouni, M.; Michaloudi, E. MAPKs and HSPs' Activation of a Natural Daphnia magna Population in a Man-Perturbed Lake: Implications of Ecological Significance. Water 2021, 13, 283. [CrossRef]

36. Papaioannou, G.; Loukas, A.; Vasiliades, L. Flood Risk Management Methodology for Lakes and Adjacent Areas: The Lake Pamvotida Paradigm. Proceedings 2018, 7, 21. [CrossRef]

37. Dibaba, A. Lake Qooqa as a Narrative: Finding Meanings in Social Memory (A Narrative Inquiry). Humanities 2021, 10, 77. [CrossRef]

38. Siepak, J.; Burchardt, L.; Pełechaty, M.; Osowski, A. Hydrochemical Research in the Wielkopolski National Park; UAM Poznań: Poznań, Poland, 1999; ISBN 83-908178-4-5. (In Polish)

39. Ferral, A.; Solis, V.; Frery, A.; Orueta, A.; Bernasconi, I.; Bresciano, J.; Scavuzzo, C.M. Spatio-temporal changes in water quality in an eutrophic lake with artificial aeration. J. Water Land Dev. 2017, 35, 27-40. [CrossRef]

40. Lawniczak-Malińska, A.E.; Achtenberg, K. Indicator Values of Emergent Vegetation in Overgrowing Lakes in Relation to Water and Sediment Chemistry. Water 2018, 10, 498. [CrossRef]

41. Solarek, K. The reactivation of Warsaw oxbow lakes as a leitmotiv of urban design. J. Water Land Dev. 2020, 45, 165-170. [CrossRef]

42. Hasan, F.; Alam, N.E.; Salam, M.; Rahman, H.; Paul, S.; Rak, A.; Ambade, B.; Islam, A.T. Health Risk and Water Quality Assessment of Surface Water in an Urban River of Bangladesh. Sustainability 2021, 13, 6832. [CrossRef]

43. Kujawiak, S.; Makowska, M.; Mazurkiewicz, J. The Effect of Hydraulic Conditions in Barbotage Reactors on Aeration Efficiency. Water 2020, 12, 724. [CrossRef]

44. Mazurkiewicz, J.; Mazur, A.; Mazur, R.; Chmielowski, K.; Czekała, W.; Janczak, D. The Process of Microbiological Remediation of the Polluted Słoneczko Reservoir in Poland: For Reduction of Water Pollution and Nutrients Management. Water 2020, $12,3002$. [CrossRef]

45. Voytovych, I.; Malovanyy, M.; Zhuk, V.; Mukha, O. Facilities and problems of processing organic wastes by familytype biogas plants in Ukraine. J. Water Land Dev. 2020, 45, 185-189. [CrossRef]

46. Witaszek, K.; Pilarski, K.; Niedbała, G.; Pilarska, A.A.; Herkowiak, M. Energy Efficiency of Comminution and Extrusion of Maize Substrates Subjected to Methane Fermentation. Energies 2020, 13, 1887. [CrossRef]

47. Li, C.; Wang, T.; Zhang, M.; Xu, J. Maternal Environment Effect of Warming and Eutrophication on the Emergence of Curled Pondweed, Potamogeton crispus L. Water 2018, 10, 1285. [CrossRef]

48. Verhoeven, M.R.; Glisson, W.J.; Larkin, D.J. Niche Models Differentiate Potential Impacts of Two Aquatic Invasive Plant Species on Native Macrophytes. Diversity 2020, 12, 162. [CrossRef]

49. Łoboda, A.M.; Karpiński, M.; Bialik, R.J. On the Relationship between Aquatic Plant Stem Characteristics and Drag Force: Is a Modeling Application Possible? Water 2018, 10, 540. [CrossRef]

50. Polakowska, M. Rośliny Wodne; WSIP: Warsaw, Poland, 1992.

51. Kłosowski, S.; Kłosowski, G. Rośliny wodne i bagienne; MULTICO Oficyna Wydawnicza: Warszawa, Poland, 2007.

52. Meng, F.; Chi, J. Interactions between Potamogeton crispus L. and phenanthrene and pyrene in sediments. J. Soils Sediments 2015, 15, 1256-1264. [CrossRef]

53. Strippel, F.; Wilken, D.; Rauh, S.; Bontempo, G.; Hofmann, F.; Strippel, F.; Kramer, A.; Ricci-Jürgensen, M.; Fürst, M. Biowaste to Biogas, 1st ed.; Fachverband Biogas: Freising, Germany, 2016; Volume 1.

54. Chen, L.; Xing, L.; Han, L. Renewable energy from agro-residues in China: Solid biofuels and biomass briquetting technology. Renew. Sustain. Energy Rev. 2009, 13, 2689-2695. [CrossRef]

55. Toor, S.S.; Rosendahl, L.; Rudolf, A. Hydrothermal liquefaction of biomass: A review of subcritical water technologies. Energy 2011, 36, 2328-2342. [CrossRef]

56. Bridgwater, A.V.; Peacocke, G.V.C. Fast pyrolysis processes for biomass. Renew. Sustain. Energy Rev. 2000, 4, 1-73, ISSN 1364-0321. [CrossRef]

57. Goldyn, R.; Podsiadlowski, S.; Kowalczewska-Madura, K.; Dondajewska, R.; Szelag-Wasielewska, E.; Budzynska, A.; Domek, P.; Romanowicz-Brzozowska, W. Functioning of the Lake Rusalka ecosystem in Poznan (western Poland). Oceanol. Hydrobiol. Stud. 2010, 39, 65-80. [CrossRef] 
58. EEA Report No 6/2013 ISSN 1725-9177 EU Bioenergy Potential from a Resource-Efficiency Perspective. Available online: https://www.eea.europa.eu/publications/eu-bioenergy-potential (accessed on 16 May 2021).

59. LECO. Operating Manual for Thermogravimetric Analyzer. 2003. Available online: https://www.leco.com/product/tga801 (accessed on 20 May 2021).

60. ASTM E1131-08(2014) Standard Test Method for Compositional Analysis by Thermogravimetry. Available online: https: / / www.astm.org/Standards/E1131.htm (accessed on 20 May 2021).

61. TAPPI. T $204 \mathrm{~cm}-07-S o l v e n t$ Extractives of Wood and Pulp; Standards Technical Association of the Pulp and Paper Industry: Atlanta, GA, USA, 2007.

62. Seifert, K. Zur Frage der Cellulose-Schnellbestimmung nach der Acetylaceton-Methode. Das Pap. 1960, 14, 104-106. (In German)

63. TAPPI. T-222 om-06-Lignin in Wood and Pulp; Standards Technical Association of the Pulp and Paper Industry: Atlanta, GA, USA, 2006.

64. TAPPI. T 9 wd-75-Holocellulose in Wood; Standards Technical Association of the Pulp and Paper Industry: Atlanta, GA, USA, 1975.

65. DIN 51731. In Testing of Solid Fuels—Compressed Untreated Wood-Requirements and Testing; Deutsches Institut für Normung E.V: Berlin, Germany, 1996.

66. LECO. Operating Instructions for CHN628 Elemental Analyzer. 2011. Available online: https://eu.leco.com/images/AnalyticalApplication-Library/CHN628_BIOMASS_203-821-510.pdf (accessed on 20 May 2021).

67. DIN 51900-2:2003-05. Testing of Solid and Liquid Fuels-Determination of the Gross Calorific Value by the Bomb Calorimeter and Calculation of the Net Calorific Value-Part 2: Method Using Isoperibol ot Static, Jacket Calorimeter. 2003. Available online: https: / / www.engineerwebs.org/home/83432-DIN-51900-2-2003-05.html (accessed on 20 May 2021).

68. ISO 18134-3:2015. Solid Biofuels—Determination of Moisture Content_Oven Dry Method_Part 3: Moisture in General Analysis Sample. 2015, p. 5. Available online: https:/ / www.iso.org/standard/61637.html (accessed on 20 May 2021).

69. Norm DIN 38414-8. Deutsche Einheitsverfahren zur Wasser-, Abwasser- und Schlam-muntersuchung; Schlamm und Sedimente (Gruppe S). Available online: https:/ / www.beuth.de/de/norm/din-38414-17/266428976 (accessed on 20 May 2021).

70. Bestimmung des Faulverhaltens (S 8). In German Standard Methods for the Examination of Water, Waste Water and Sludge; Sludge and Sediments (Group S); Determination of the Amenability to Anaerobic Digestion (S 8); Beuth Verlag GmbH: Berlin, Germany, 1985.

71. Wilén, C.; Rautalin, A. Spontaneous Ignition-A Hazard in Biomass-Fueled Power Production. In Advances in Thermochemical Biomass Conversion; Springer: Berlin/Heidelberg, Germany, 1993; pp. 1645-1658. [CrossRef] 